\title{
Recent trends in irregular maritime immigration to the Canary Islands
}

Authors: por Dirk Godenau, Daniel Buraschi and Vicente Manuel Zapata Hernández

The recent intensification in irregular maritime migrations in the Atlantic route through the Canary Islands, which is employed to reach the European mainland from Africa, coincides in time with the presence of the coronavirus pandemic and incorporates some novelties involving a flow that has been present in the archipelago's evolution for almost three decades. It also exhibits many similarities with the permanent manifestation of this influx, even though the scant planning and weak response initially implemented in an effort to comprehensively manage this migration has placed the phenomenon at the forefront of the current affairs and debate in the region. As a result, a social context of enormous uncertainty due to the health and economic crisis, the direct and almost real-time knowledge of the outcome of many crossings thanks to social media, together with the confusion sown by how this mobility is being managed, all raise the need to reconsider its analysis in order to ascertain its current characteristics and keys to its understanding.

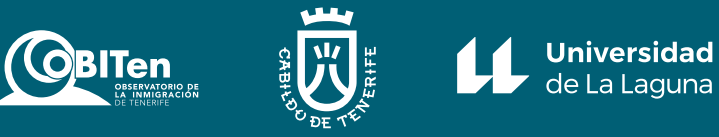




\section{Conceptual clarification: what do we understand by irregular immigration?}

Irregular immigration is a highly publicised issue of social and political relevance. Different terms are used to refer to irregular immigrants, suc $h$ as illegal, undocumented or clandestine, each with different conceptual, social and political implications (Echevarría, 2020). In fact, as Cvajner and Sciortino (2010: 390) note, "behind the notion of irregular migration there is today a set of interpretative frames, stereotypes, folk wisdom, icons and slogans that makes it a part of a complex symbolic discourse". The term illegal, for example, in addition to being incorrect from a conceptual point of view, since no person is illegal, is a concept that seeks to dehumanize, criminalize and exclude migrants, often legitimising punitive and discriminatory measures (Düvell, 2011).

In keeping with the International Organization for Migration, we can define irregular immigrants as "people who move outside the regulatory norms of the sending, transit and receiving countries. [...] From the perspective of destination countries it is entry, stay or work in a country without the necessary authorization or documents required under immigration regulations. From the perspective of the sending country, the irregularity is for example seen in cases in which a person crosses an international boundary without a valid passport or travel document or does not fulfil the administrative requirements for leaving the country" (IOM, 2006: 40).

Based on this definition, an initial aspect to consider is that the adjective "irregular" does not refer to a characteristic of migrants, but to a relationship between a migrant or a group of migrants and a set of norms established by a State or group of States (De Genova, 2002).

The term can also refer to different realities. On the one hand, the non-compliance by migrants with the rules of entry; for example, individuals who have entered Spain without the necessary authorisation, as in the case of irregular maritime migrations. On the other, an irregular stay; for example, people who have entered regularly with a tourist visa and who have stayed in the country beyond the allowed time, or people who for various reasons have not been able to renew their residency permit because they are unemployed. Highly disparate situations can exist, with very different legal, social and economic implications.

The separation between regular and irregular is not always clear, and there are legally ambivalent spaces, moments of irregularity that depend on administrative procedures. The same person can also go through different stages of regularity and irregularity over the course of their migratory journey (Echevarría, 2020).

The geographic routes of African emigration to the European continent vary in terms of their starting points or countries of departure, not all of them African, since Africa is also a transit area for people from other continents. Similarly diverse are the routes taken before leaving the African continent, with many of the people travelling to the shores of the Mediterranean, and only to a lesser extent to the edges of west Africa. Also worth considering is the maritime or land environment used to cross the European border. The Canary Islands are an example of the island territories of Europe that are located in the interstitial spaces between continents, some of which (the minority) are more exposed than others to the arrivals of migratory flows by sea. 
This part of the migratory journey, the sea crossing, features some peculiarities: first, the ocean is an environment that requires specific means of transport (boats); second, the use of said means entails the high probability that migrants will be grouped together as passengers on a boat; third, navigation, especially on risky routes, requires specific knowledge, which turns the presence of a skipper with sufficient expertise into a strategic asset to minimise the probability of a shipwreck; fourth, the control of maritime spaces poses specific technological challenges (surveillance radars, aerial resources, vessels). It is not that monitoring maritime areas is necessarily more difficult (compared to land areas), but it is a task with its own attributes.

The geo-strategic position of the islands in the maritime routes stems from the fact that they belong to continental countries (migration destinations), meaning that arriving at one of them implies having entered the European (community) space. However, the probability of detecting the arrival or stay in island areas is high, and this, in turn, reduces the likelihood of continuing the journey to the mainland irregularly (due to the need to use collective air or sea transport, which is much more controlled than overland travel). The islands are only appealing as transit areas if the possibility exists of continuing (or being diverted) to continental spaces after being intercepted (Godenau, 2012).

\section{The Canary Islands in the network of routes}

\subsection{Evolution of the Africa-EU migration routes}

The Atlantic route of irregular maritime migrations through the Canary Islands is part of a set of itineraries that channel a fraction of African emigration to Europe. The data on these routes does not include African nationals entering the European Union with permission, nor does it include those who gain irregular access by other means (such as forged documents).

The general evolution of these routes from 2018 to 2020 is characterised by the following trends: a) a clear decrease in the total number of interceptions after 2018 (see map 1); b) this downward trend is also present in the western Mediterranean route that connects with mainland Spain and the Balearic Islands (Frontex, 2020:8); c) by contrast, the Canaries route experienced substantial growth (Frontex, 2020:26); d) the number of additional people arriving via the Canaries route was lower than the reduction in the Mediterranean route in 2019, but in 2020, the increase in the Atlantic route began to outpace the decrease in the Mediterranean route. As Graph 1 shows, the importance of the Atlantic route has been low in recent years compared to the rest, an observation that is compatible with the high growth rates in the number of arrivals to the Canary Islands, particularly in 2020. 
Map 1

Routes of irregular migration to

Europe in 2019.

Source

Frontex (2020: 24).

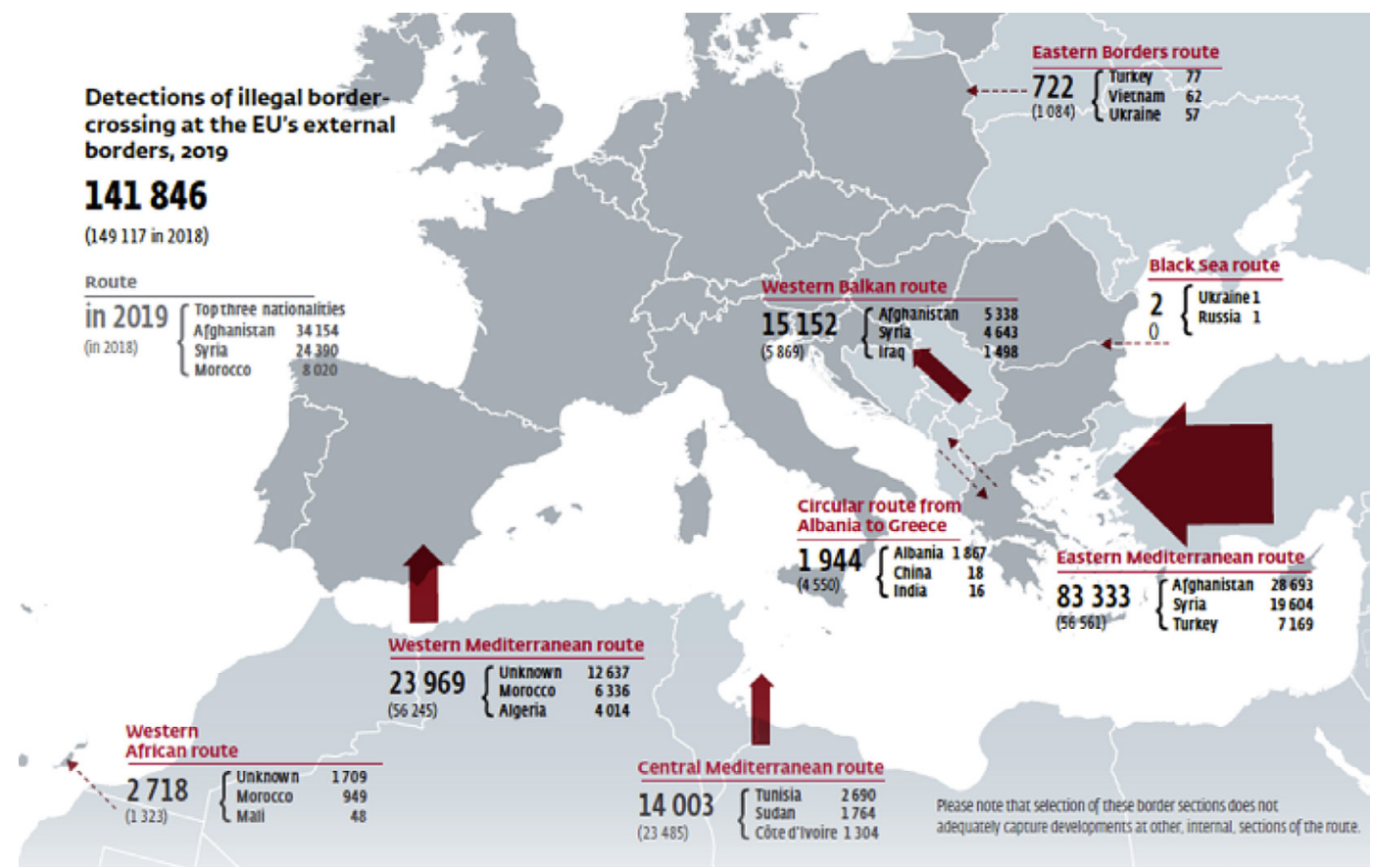

Number of persons on

irregular sea crossings

by route from 2018 to

2020.

Fuente

Frontex.

Compiled by authors.

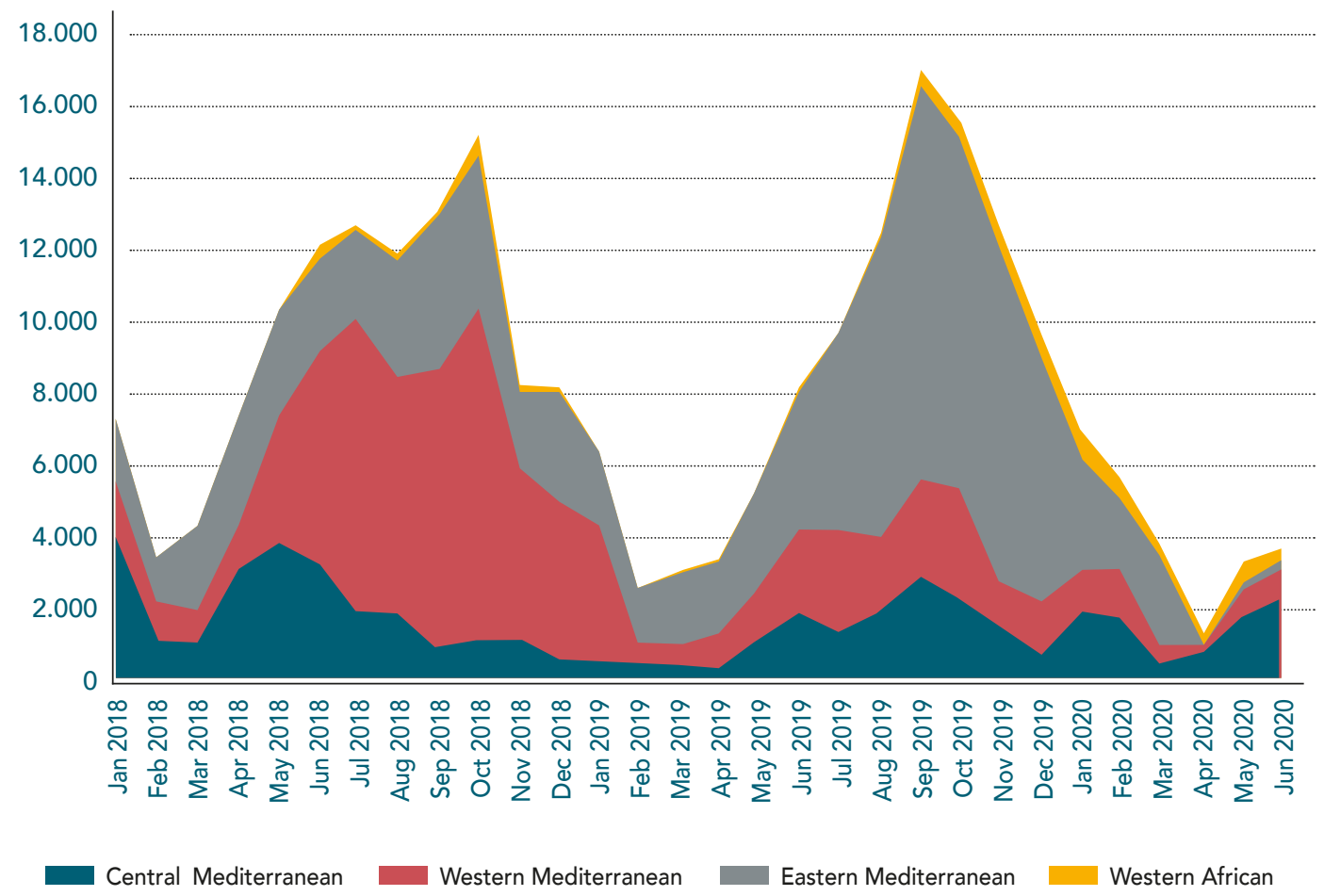

Graph 2 shows this substantial increase in the number of irregular maritime border crossings that were detected between January 2018 and June 2020, an increase that led to a rise in the prominence of the Atlantic route in all maritime routes. While this route accounted for $1 \%$ of traffic in early 2018 , in the first eight months of 2020 it already exceeded $6 \%$. This rise is the combined result of a higher number of arrivals on this route and a drop in total maritime interceptions between Africa and Europe. 


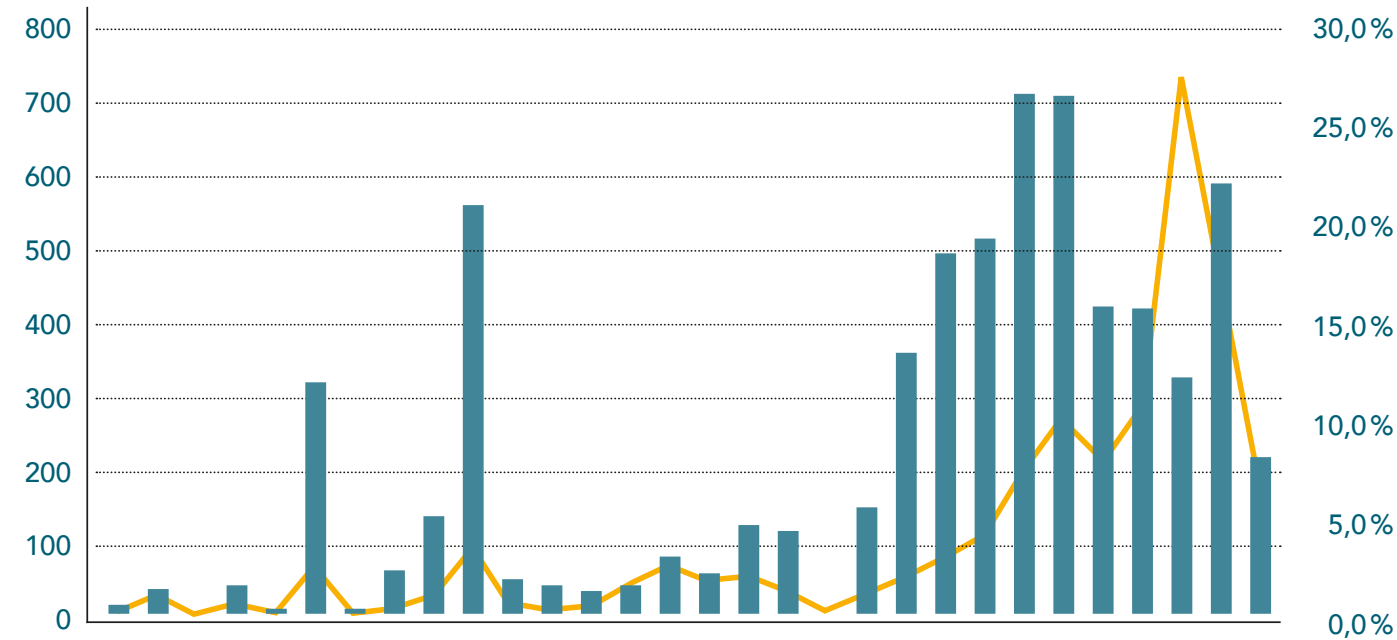

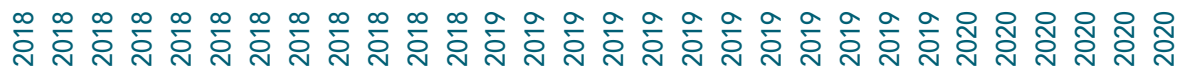

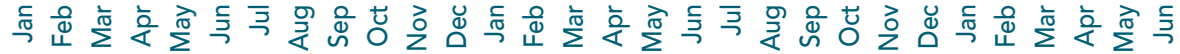

Number of interceptions.

. $\%$ of west African route in all maritime routes between Africa and Europe (axis on the right)

On the west African route, the statistics produced by Frontex indicate a high percentage of intercepted persons whose nationality is unknown (55.6\% in the period from January 2018 to August 2020) ${ }^{1}$. Of the remaining individuals whose nationality was known, the majority were Moroccans (Table 1), at $30.6 \%$. The prominence of this bordering country in arrivals was very high until July 2019. It then decreased rapidly due to the increase in migrants from sub-Saharan origins. This pattern of nationalities should not be confused with the countries of departure of the vessels, because this geographical criterion of the points of departure from the African continent does not yet show a clear shift towards countries further south, such as Senegal (Frontex, 2020:26), which in turn affects the duration of the crossings and the boats used.

\begin{tabular}{l|c|c}
\hline Nationality & People intercepted & $\%$ \\
\hline Unspecified Sub-Saharan Africans & 3,593 & 53.3 \\
\hline Morocco & 2,064 & 30.6 \\
\hline Mali & 349 & 5.2 \\
\hline Senegal & 223 & 3.3 \\
\hline Unknown & 152 & 2.3 \\
\hline Ivory Coast & 103 & 1.5 \\
\hline Gambia & 96 & 1.4 \\
\hline Guinea & 89 & 1.3 \\
\hline Comoras & 25 & 0.4 \\
\hline Guinea Bissau & 17 & 0.3 \\
\hline
\end{tabular}

1 The entities that oversee the migrant reception process likely know the more about their places of origin. The general trend seems to point to the growing prominence of sub-Saharan origins, and Mali in particular in recent times, and that even the propensity of migrants to carry documentation may be growing in anticipation of a low probability of return, documentation the migrants can use later as they continue on their migratory journey.
Graph 2

Number of persons crossing the maritime border on the west African route irregularly and prominence of maritime routes between Africa and Europe from 2018 to 2020 ( \%).

\section{Source}

Frontex.

Compiled by authors.

\section{Table 1}

Nationalities of persons intercepted irregularly crossing the Atlantic route by sea via the Canary Islands between January 2018 and August 2020 ( \%).

\section{Surce}

Frontex.

Compiled by authors. 


\begin{tabular}{l|c|c}
\hline Nationality & People intercepted & $\%$ \\
\hline Algeria & 11 & 0.2 \\
\hline Cameroon & 4 & 0.1 \\
\hline Bangladesh & 3 & 0.0 \\
\hline Mauritania & 3 & 0.0 \\
\hline Burkina Faso & 2 & 0.0 \\
\hline Sierra Leone & 2 & 0.0 \\
\hline Congo (Brazzaville) & 1 & 0.0 \\
\hline Gabon & 1 & 0.0 \\
\hline Libya & 1 & 0.0 \\
\hline Ethiopia & $\mathbf{6 , 7 4 0}$ & 0.0 \\
\hline Total & & $\mathbf{1 0 0 . 0}$ \\
\hline
\end{tabular}

Why is the west African route resurging now? It is impossible to quantify the importance of the various factors causing this change, but the primary causes can be ranked: first, the changes in the relative permeabilities of the various routes, with greater sealing of the western Mediterranean route from the latter half of 2019; second, the relaxation of cooperative efforts to control the west African coast; third, an increase in political and economic instability in certain countries of origin of sub-Saharan emigration, such as Mali, and worsening relations between Mali and Senegal and Burkina Faso; fourth, a phenomenon of cumulative causation in the reactivation of the Atlantic route ${ }^{2}$; fifth, and related to the above, low percentages of return to countries of origin.

In this regard, it should be noted that the majority of individuals in crossings from subSaharan countries in the most recent stage were from Mali, according to the interviews carried out with the staff of reception facilities. They account for a large part of the group of unspecified Sub-Saharan Africans contained in the statistics. They comprise the largest contingent of immigrants along with Moroccans, the difference being that Moroccans arrive in smaller but more frequent groups, while the Sub-Saharan Africans do so on vessels from more southerly origins, with more occupants but spaced out over time. In all, the forecasts collected point to an intensification in this last flow during the final quarter of the year, when the Atlantic currents from the $20^{\text {th }}$ parallel (Nouadhibou) towards the north are less dangerous than in the mid-summer months (Vélez, 2015).

\footnotetext{
2 In the field of migratory theories, a distinction is made between those that explain the beginning of the process (and the routes) and those that explain its consolidation and growth over a given period. The factors that influence this cumulative causation over time include the creation and communication of information on how to organise the migratory project (imitation effect), the establishment of organisational structures (see the bibliography on migratory markets; López Sala and Godenau, 2017) and the benefits of existing links with family and friends at the destination (migratory networks).
} 


\subsection{Risk factors on the west African Atlantic route}

The Atlantic route is extremely hazardous, according to many people and specialised organisations, especially when the departures are made from more southerly points (Vélez, 2012). This is because the stretch of sea that vessels must frequently cross is extensive, and its conditions are not very favourable for vessels that were not designed for this type of voyage. The approximately $110 \mathrm{~km}$ that separate the coasts of Tarfaya, in Western Sahara, from the nearest point of the Canary archipelago, can grow to as much as 1,500 km for the coast of Senegal ${ }^{3}$. Furthermore, arrivals regularly take place when the passengers are at their worst, since they often spend many days at sea, which reduces their physical and mental capacities. As a result, when they are intercepted, they exhibit serious symptoms of exhaustion and disorientation.

\begin{tabular}{|c|c|c|c|c|}
\hline Año & Mes & Fallecidas & Desaparecidas & $\begin{array}{l}\text { Total fallecidas } \\
\text { y desaparecidas }\end{array}$ \\
\hline \multirow{7}{*}{2019} & March & & 19 & 19 \\
\hline & May & 3 & 1 & 4 \\
\hline & July & 7 & 4 & 11 \\
\hline & August & 1 & 22 & 23 \\
\hline & October & 6 & 1 & 7 \\
\hline & November & 9 & 2 & 11 \\
\hline & December & 70 & 40 & 110 \\
\hline \multirow{8}{*}{2020} & January & 2 & & 2 \\
\hline & February & 5 & 21 & 26 \\
\hline & March & 1 & 21 & 22 \\
\hline & April & 2 & 39 & 41 \\
\hline & May & 3 & 4 & 7 \\
\hline & July & 28 & 75 & 103 \\
\hline & August & 27 & 13 & 40 \\
\hline & September & 2 & & 2 \\
\hline Total & & 166 & 262 & 428 \\
\hline
\end{tabular}

Table 2

Number of deceased and missing persons on the Atlantic route by month and year between 2019 and 2020.

\section{Fuente}

Compiled by authors based on data from the Missing Migrant Project.

According to data from the International Organization for Migration's Missing Migrant Project (MMP), from 1 January, 2019 to 22 September, 2020 there were 27 shipwrecks on the maritime route to the Canary Islands, with a total of 428 deceased or missing persons, 185 in 2019 and 243 in 2020 (Table 2). Despite not knowing the sociodemographic profile of the majority of the individuals who were involved in the shipwrecks, the deaths of at least 7 minors were able to be documented.

3 Vélez (2012) identifies some of the main points of departure for the various maritime itineraries that may be taken along the Atlantic route. These include, from north to south, along the African coast, the following: Tarfaya, in Morocco; El Aaiún, Cabo Bojador, Dakhla and Güera, in the territories of Western Sahara; Nouadhibou, Cabo Blanco and Nouakchott, in Mauritania; Saint Louis, Kayar, Dakar, Mbour and the southern area of Casamance, in Senegal; Barra and Gunjur, in Gambia. In the case of Morocco, Tan Tan and Sidi Ifni, further north, are also worth mentioning. 
It should be noted that despite efforts to document deaths along migration routes, there are strong indications that many more people have disappeared without a trace while trying to reach Spain. The NGOs operating in Spain and in various African countries have received many additional reports from the relatives of persons who disappeared in shipwrecks, but they could not be confirmed and the MMP does not record any of these deaths or disappearances. For example, just in the first quarter of 2020, the Caminando Fronteras NGO tallied 12 shipwrecks on the Canary Islands route, with a total of 245 victims.

The risk involved in a maritime crossing is determined by various interrelated factors: a) of the physical-environmental conditions, mention must be made of the sea state (waves, currents), meteorological conditions (temperature, wind, sun, visibility) and distance (duration of the crossing); b) the most significant factors involving the resources used include the vessel (ability to withstand adverse conditions, load capacity), knowledge of navigation techniques (experienced skipper), engine (reliability, power, crossing speed) and communications equipment (message to request rescue); c) the probability of rescue by other vessels, whether operated by rescue services or not, plus remote surveillance of the ocean surface by aeroplanes or other technological methods.

Almost everyone on board has little or no experience at sea, they are exposed during the voyage to adverse conditions (overcrowding, food and water shortages, exposure to the elements) and they are vulnerable (children, pregnant women, people weakened by previous travel). Moreover, a non-negligible percentage of the people who start the journey are unaware of the details beforehand. This is indicative of the low levels of transparency and predictability that characterize these irregular migrations. In this context, the strategies used to circumvent this uncertainty mainly involve communication: informing relatives and friends of the journey, calls to emergency telephones, contact with NGOs, etc.

\section{Reception at the destination}

The way that vessels arriving in the archipelago with immigrants on board are received is complicated by the variety of the circumstances involved, since the method of access is not always the same and has been evolving over time. The original small boats were later joined by dugout canoes, and even rickety merchant ships with a deeper draught have reached the coasts of the Canary Islands, including inflatable boats in this latest migratory spike. The departure points, itineraries and environmental conditions also influence the variability of the situations that can be encountered (Vélez, 2015).

Vessels can be intercepted on the high seas or near the insular coastline by the Maritime Service of the Civil Guard or by Maritime Rescue, either on search missions or alerted by other ships or aircraft. Some reach the nearest ports under their own power, and it is not uncommon for them to arrive at an accessible beach, although there have also been cases, resulting in tragedies, of encounters with the islands in extremely dangerous places that are not very conducive to accessing land. Some are even found adrift with all or some of their passengers already deceased.

The reception process involves many people and groups from different entities, organisations and institutions, with the logistics varying depending on the method and place of access, and even on the number of people who arrive on the vessel. Additional considerations include the health of the migrants as well as the occupancy rates of 
reception centres as a result of previous arrivals. All of this has been complicated in recent months by the coronavirus pandemic, as the occupants of the vessels are screened for SARS-CoV-2.

\subsection{First stage: initial contact and health care}

As noted earlier, vessels with migrants that plan to sail to the Canary archipelago can achieve their purpose in various ways. They are increasingly intercepted before they approach the islands' coastline, sometimes a great distance away, by units from Maritime Rescue, which has two Coordination Centres in the port areas of Las Palmas de Gran Canaria and Santa Cruz de Tenerife. They are also intercepted by Civil Guard patrol boats, which are tasked with controlling irregular immigration in Spanish territorial waters.

Depending on the operation, the two organisations can coordinate to effect the rescue, which usually occurs after the vessel is detected by SIVE (Integrated External Surveillance System) radars installed on the islands of Fuerteventura and Lanzarote. The vessels are sometimes detected by the Spanish Army's Air Rescue Service, located at the Gando Air Base on the island of Gran Canaria, which has also evacuated individuals in ill health, and even dropped life rafts from the air when required by circumstances.

Notifications from various NGOs that are active in the areas of origin are becoming more and more common. These NGOs are contacted by people who become aware of the departure of a vessel with migrants, or who are informed by the migrants on board these vessels, sometimes while on the boat, when there is telephone coverage and in highly dangerous situations. The maritime traffic that is sailing in the sea south of the Canary Islands is often asked to help escort the boats until rescue personnel arrive; it is these vessels that in many cases report the presence of small boats, dugout canoes or inflatable boats sailing in open waters.

In the framework of this latest migratory episode, many voices have questioned the operation of the SIVE, especially given the repeat direct arrivals to the coastline of most of the islands, including the western island of La Palma. The Canary Islands Regional Coordination Centre (CCRC), which operates this system, notes the complexity of its work, given the extensive sea surface that must be surveilled and the problems involved in detecting many vessels that, due to their small size, can be confused with waves, according to statements made by CCRC officials to different regional media outlets.

In other cases, the boats make landfall on their own and the immigrants either remain in place or disperse immediately upon arrival. Personnel from law enforcement agencies, including local police, report to these landfall sites, often alerted by residents or passersby. The Red Cross and health resources from the Canary Islands Emergency Service (SUC), mobilised by the 112 Emergency and Security Coordination Centre (CECOES), are also dispatched. If the immigrants flee the site, a search party is organised in the area.

The corresponding police forces activate the Coordination and Collaboration Protocol of the Autonomous Community of the Canary Islands, one of the consequences of the cayuco crisis (2006) for dealing with this type of immigration, and which involves "the close coordination of all the relevant organisations and the maritime, air, and land resources that are used in response" (Order PRE/3108/2006), and which resulted in the creation of the Regional Coordination Centre of the Canary Islands, mentioned earlier, whose operations are directed from Las Palmas de Gran Canaria. 
A pre-reported arrival at a port activates the Red Cross's humanitarian assistance to immigrants service (ERIE), which involves personnel from this organisation, along with its volunteers. The field hospital includes a screening and health care module, with a change of clothes, water, hot drinks and meals being provided in other areas. The migrants' basic details are also collected: name, age and origin. If serious situations or pregnancies are identified, they are transferred to hospital. At this point, men, women and minors are separated, unless family ties are identified. An effort is also made to identify female victims of trafficking and gender violence.

The pandemic and the need to administer PCR tests to the migrants who arrive on each vessel require the implementation of a special protocol, which is applied once the migrants are identified by the National Police. The data collection and identification processes are essential so that the primary care unit of the Canary Islands Health Service can provide the corresponding tests, either on the docks themselves or in the warehouses set up in the port areas.

The increase in migration has led to a search for methods to receive a significant number of arrivals in a short time, even resulting in the setting up of improvised camps or industrial warehouses in the port areas, solutions that are called into question from all sides as the migrants' stay is prolonged more than desired, or even past legally established deadlines. This has happened, for example, in the port of Arguineguín, in the municipality of Mogán in the south of Gran Canaria, where over 400 individuals have been housed in tents used to separate different groups of arriving migrants. Or in the port of La Luz in Las Palmas de Gran Canaria, where a storage warehouse was set up to house different groups of migrants starting in the spring of 2020. A warehouse has also been set up in the port complex of Puerto del Rosario in Fuerteventura.

Coinciding with the increase in the number of arrivals and the problems added by the pandemic, different alternatives have been proposed involving the opening of a camp or operational centre with a greater capacity and more services in the port area of Arinaga in the east of Gran Canaria, although this was not built in the end due to a lack of institutional agreement. People who have tested positive for COVID-19 (only 2 or $3 \%$ of those tested, according to reception personnel) have also been diverted to this same location, although to another facility (a school dormitory in Playa del Cabrón), where they remained quarantined in isolation. People who test negative but who have been in close contact with carriers of the virus are quarantined in another centre in the town of Tunte (San Bartolomé de Tirajana). Those who test negative and have had no contact with carriers are housed in hostels or hotels, since the immigration detention centres have been closed for much of 2020 .

\subsection{Second stage: Identification and administrative processing}

After they are treated by the Red Cross and regional healthcare workers, the migrants are processed by the National Police, which reports the detention of the immigrants to the various immigration departments of the national government and to the national government's own office in the Canary Islands. A 'Littoral Document' is also completed with information on the number of occupants, type and physical characteristics of the boat, place of origin and disembarkation, identity and nationality of the individuals or skippers in charge of the vessel, etc.

The migrants are read their rights, including their right to health care and legal assistance - the role of interpreters being fundamental here -, and the signed originals are forwarded 
to the corresponding court. The immigrants are also photographed and their fingerprints are taken. Any immigrants who are identified are informed that they will be returned to their country of origin, although this has been interrupted in recent months due to the closure of borders as a result of the pandemic. This could be reactivated in short order, however, by resorting to the specific readmission agreements (Morocco, Algeria, GuineaBissau and Mauritania) or framework cooperation agreements (Gambia, Guinea and Cape Verde) that Spain has signed with various African countries.

The corresponding consulate is informed of this detention for the purpose of removal, and given the identifying information on the immigrant and the internment measures employed. If the consulate cannot be notified, or if it is not based anywhere in the country, the report is sent to the Ministry of Foreign Affairs. If the immigrant requests it, his/her relatives residing in Spain will be informed of the internment measure, which, pursuant to the applicable law, may not exceed 60 days.

During times of lower migration flows, migrants are transferred from port facilities or other reception sites directly to Temporary Immigrant Detention Centres (CETI), where they can be held for up to 72 hours. These are temporary housing facilities intended to provide basic social services and benefits to immigrants and asylum seekers while their identification and medical papers are processed prior to any decision being made involving their future in the country.

There is some experience on the use of CETIs, although on an open-detention basis, following the release of the migrants from the CIEs following the maximum 60-day stay, when the CIEs were still in use. There are CETIs in Playa de las Américas (Arona, Tenerife) and in Las Palmas de Gran Canaria. On different occasions, more temporary spaces of this type have been set up on these and other islands involving temporary and, in certain cases, rather inadequate facilities.

\subsection{Third stage: Different outcomes}

During the first phases already outlined, the incoming migrants are screened since, depending on their age, health situation, ability to identify them, asylum request, or even a request to send them on from the archipelago to other locations in the country, they will be processed differently or they will be assigned to a specific facility in the Canary Islands, whether a $\mathrm{CIE}$, a humanitarian reception centre, a centre for minors, or elsewhere.

The pandemic has had a significant effect on this process, since the CIEs, for example, ceased operating for several months starting in April, when infections spread between their occupants and the personnel in charge of the centres, and also because deportations or returns to their countries of origin could not be effectuated. This closure also occurred in an increasingly controversial context involving their very existence and operation, with a large number of complaints detailing the multiple deficiencies present in the centres. However, the increased influx and the inability of the reception system to fully deal with the number of arrivals has led to the reopening of the centres located on the main islands.

It should be noted that $\mathrm{CIEs}$ are non-penitentiary public facilities operated by the National Police for the Ministry of the Interior, and are intended to hold immigrants in protective custody while they await deportation or return. Of the eight CIEs in Spain, three are located in the Canary Islands: Barranco Seco, in Las Palmas de Gran Canaria; Hoya Fría, in 
Santa Cruz Tenerife; and El Matorral, close to the Fuerteventura airport, closed since 2018. There are also the facilities located at the Lanzarote airport.

In the case of minors travelling without an adult, and assuming their underage status, they are transferred to the corresponding Child Protection Services. Once their underage status is confirmed using medical tests to determine their skeletal or dental age, the court is petitioned to include them in the Immediate Reception Programme for Unaccompanied Foreign Minors. They become wards of the Government of the Canary Islands, delegated to the island councils, which assign them to permanent centres in the reception network, or to emergency facilities. For all intents and purposes, they are considered legal residents.

As concerns the women who arrive by sea, there are three possibilities. In the case of pregnant women, the decision to return them will be held in abeyance when this action could pose a risk to the pregnancy or to the mother's health. As for women who arrive alone or with minor children, considering the vulnerable situation they must endure during their departure and voyage - and potentially also in reception areas -, the court is not usually petitioned to order their internment in a CIE because, to a large extent, these centres are not intended for them and because they sometimes cannot be returned. In this case, they are cared for by the Red Cross through the humanitarian assistance programme of the Secretary of State for Migration.

Particular attention is also paid to the existence of possible victims of human trafficking, gender violence or any other crime. Considering the complexity of this type of situation and the length of time it takes to identify and ascertain it, an effort is made to network all the agents involved in handling this migratory influx. Both during the identification phase of the victims and during the recovery and reflection period (up to 90 days in the case of trafficking), the execution of any deportation or return order eventually agreed by the corresponding judicial body will be suspended, with the government being responsible for the care, safety and protection of the victim and their minor or disabled children.

The recent application of a ruling by the Court of Justice of the European Union that facilitates the claim for international protection for justified reasons seems to point to a profound change in terms of the possibility of internment and prompt return of individuals whose asylum application is accepted for consideration. This means that they must be assigned priority humanitarian reception status in an open detention regime by the Ministry of the Interior, managed in the Canary Islands by the Spanish Commission for Assistance to Refugees (CEAR) or the Red Cross, and which provides for their basic needs and their housing in available hostels or community spaces - both in the archipelago and on the mainland - for a maximum of nine months, extendable by a further six. This is an inclusive programme that also offers job training for the personal betterment of immigrants.

\section{Challenges and perspectives}

Given the above, it seems that even today, despite the efforts made and "after more than two decades of small boats arriving at Spanish coasts, there is still no coherent, coordinated and shared model for managing this phenomenon throughout Spain" (González Beilfuss, 2019:167). Furthermore, the reactivation of the Atlantic route through the Canary Islands shows that a previous pattern is repeating itself, something that should have been foreseeable once circumstances such as those described above converge (Godenau, 2019:161). 
This new episode of intensification has several elements in common with the previous one that occurred in the first decade of the 21st century: first, this phenomenon is the result of changes in the permeability of other places on the European border, particularly on the western Mediterranean route; second, we are witnessing an evolution by phases as the departure points shift along the African coast, with a gradual increase in maritime distances from the Canary Islands and the corresponding risk for migrants; third, the increase in arrivals again reveals a reception system that is reactivated in response to events, with the corresponding negative consequences for those affected; fourth, there is a repeat of the extrapunitive discursive reactions that call for greater attention from national and supra-national organisations; fifth, foreign policies to contain departures from the African continent are resumed through bilateral agreements; sixth, the often repeated recommendations to promote the economic development of the countries of origin in order to reduce the incentive to emigrate have been ineffective.

But the new stage of intensification in the use of this route also brings with it some original elements, most notably those related to the context of the current health and socioeconomic crisis, which, on the one hand, provide an added factor of instability in the sending countries and uncertainty in transit areas, and, on the other hand, they require the need to administer PCR tests to new arrivals and manage group quarantine spaces, and make it impossible to return migrants to the countries of origin or departure, which significantly influences the three stages described in the preceding paragraphs. Another difference is that the relocation plan that allowed numerous irregular immigrants to continue their migratory journey to the mainland was suspended in recent years.

A third difference with respect to 2006 is that, currently, social media has a greater influence on public discourse than it did fifteen years ago. On the one hand, it is important to consider how widespread hate speech is online, which nurtures a dangerous breeding ground for racism and xenophobia; on the other hand, the arrival of migrants is being hyped not only by the media outlets, such as television, radio and the press, but also by numerous individuals who record images of boats arriving, to which are added derogatory, violent and discriminatory comments. These videos, photographs, memes, etc., can be widely disseminated on social media and pose the added danger of being able to represent, for those who view or read them, an apparently reliable source of information, since they are generated by locals who speak from personal experience and are outraged and frustrated. This dynamic is aggravated in the current context of health and economic uncertainty, which could negatively affect attitudes toward immigration.

And in the middle of all this, there is the inescapable goal of guaranteeing the rights of immigrants in the complex and changing context of the health crisis: effective legal assistance, medical care and respect for the necessary health prevention measures, right to apply for asylum, etc. These aspects require achieving a positive dialogue and coordination between the wide range of actors involved in managing migratory processes at various levels, as well as allocating the necessary means and resources, as was recently demanded by the Canary Forum on Immigration.

As its last work session", it expressed a "concern about the lack of means to properly care for people who are arriving in the Canary Islands", as well as about the increase in

4 The Canarian Immigration Forum hosted a session on the issue of irregular maritime immigration on 9 September, 2020, at which it unanimously approved a document with findings and demands addressed to the Government of the Canary Islands, the Spanish State and the European Union. [https://www3.gobiernodecanarias.org/ noticias/wp-content/uploads/2020/09/Conclusiones-Foro-09.9.20.pdf] 
shipwrecks and the loss of human lives, plus the proliferation of xenophobic and hate speech, directing its demands to European, Spanish and regional institutions. "There is also a need to improve the intervention and the contribution that is made by the archipelago itself and the essential social involvement, leveraging the lessons learned and the existing resources as a formula for transforming the way migration is managed in our region into a benchmark, both in terms of our internal development process and of how we are viewed abroad".

It is clear that what will abate arrivals is the implementation of consistent, long-term foreign policies in Africa that are defined, applied and evaluated in close cooperation with areas of origin and transit of migrants, that have a real impact on migratory processes and are focused on minimising the factors already mentioned that drive migratory flows. This is a known and manageable social phenomenon, not a sudden natural disaster, and it needs a permanent solution because there will always be a propensity for it to be amplified in one way or another, sometimes, as is happening on this occasion, in the framework of an exceptional situation that has complicated its management even more. This requires anticipation and planning.

\section{For more information}

CVAJNER, M. and SCIORTINO, G. (2010). Theorizing irregular migration: the control of spatial mobility in differentiated societies. European Journal of Social Theory, 13(3), 389-404.

DE GENOVA, N. (2002). Migrant "Illegality" and deportability in everyday life. Annual Review of Anthropology, 31(1), 419-447.

DE GENOVA, N. (2004). The legal production of Mexican/migrant "illegality". Latino Studies, 2(2), 160-185.

DÜVELL, F. (2011). Paths into irregularity: The legal and political construction of irregular migration. European Journal of Migration and Law, 13(3), 275-295. https://doi. org/10.1163/15718 1611X587856

ECHEVERRÍA, G. (2020). Towards a Systemic Theory of Irregular Migration: Explaining Ecuadorian Irregular Migration in Amsterdam and Madrid. Springer Nature.

GODENAU, D. (2012). An Institutional Approach to Bordering in Islands: The Canary Islands on the African-European Migration Routes. Island Studies Journal, Vol. 7, No. 1, 3-18.

GODENAU, D. (2019). Canarias: lugar de llegada y tránsito de la ruta migratoria atlántica hacia Europa. El fenómeno migratorio en España. Reflexiones desde el ámbito de la Seguridad Nacional, Government of Spain, 155-161.

GONZÁLEZ BEILFUSS, M. (2019). Migración irregular en España. Mediterráneo, Canarias y Ciudades Autónomas. El fenómeno migratorio en España. Reflexiones desde el ámbito de la Seguridad Nacional, Gobierno de España, 163-167. 
LÓPEZ SALA, A. and GODENAU, D. (2017). Delegando el control migratorio. Una aproximación a las dinámicas del outsourcing en España. In A. López Sala and D. Godenau (coords.), Estados de Contención, Estados de Retención. El control de la inmigración irregular en España. Barcelona: Anthropos, 197-223.

IOM (2006). Glossary of migrations. Geneva: International Organization for Migration (IOM).

VÉLEZ ALCALDE, F. J. (2015). La inmigración irregular por vía marítima hacia Europa del Sur. La respuesta de los Estados, Doctoral Thesis (unpublished), UNED.

Over the course of this work, the authors consulted various journalistic articles published digitally by the regional press in the Canary Islands in 2020. The authors wish to express their gratitude to José Antonio Rodríguez (Red Cross) and Txema Santana (CEAR) for their contributions to the characterisation of the reception process at the destination. The authors also consulted various OBITen reports on irregular immigration by sea, written by Amal Belleyo Belkasem and Loueila Mint El Mamy.

How to cite this article:

GODENAU, D., BURASCHI, D. and ZAPATA HERNÁNDEZ, V.M. (2020). Recent trends in irregular maritime immigration to the Canary Islands. OBITen Factsheet 8-2020. Retrieved from www.obiten. net. DOI: https://doi.org/10.25145/r.obitfact.2020.06.

The Tenerife Immigration Observatory is a joint initiative of the Tenerife Council and the University of La Laguna that is intended to provide a permanent and dynamic structure to advance our scientific knowledge of migratory movements. The OBITen carries out its activity by gathering, producing and disseminating knowledge to facilitate qualified opinions and promote the making of decisions that help to better manage migratory phenomena and their implications.

http://www.obiten.net 